\title{
Changes in cerebral oxygen consumption are independent of changes in body oxygen consumption after severe head injury in childhood
}

\author{
D S F Matthews, J N S Matthews, A Aynsley-Green, R E Bullock, J A Eyre
}

\begin{abstract}
This study examines the relation between cerebral $\mathrm{O}_{2}$ consumption $\left(\mathrm{CMRO}_{2}\right)$ and the $\mathrm{O}_{2}$ consumption of the rest of the body $\left(\mathrm{BVO}_{2}\right)$ after severe head injury. Seventy nine serial measurements of whole body $\mathrm{O}_{2}$ consumption, $\mathrm{CMRO}_{2}$, plasma adrenaline, T3, and glucagon concentrations were made in 15 children with severe head injuries receiving neurointensive care. Body $\mathrm{O}_{2}$ consumption was measured with indirect calorimetry and $\mathrm{CMRO}_{2}$ with the Kety-Schmidt technique. There was no evidence of a significant relation between $\mathrm{CMRO}_{2}$ and $\mathrm{BVO}_{2}$. Within each child there were statistically significant positive relations between $\mathrm{BVo}_{2}$ and adrenaline, T3, and glucagon. By contrast, there was only a weak significant positive relation between $\mathrm{CMRO}_{2}$ and T3.

In conclusion, $\mathrm{CMRO}_{2}$ and $\mathrm{BVo}_{2}$ seem to be determined independently after severe head injury. Thus therapeutic measures aiming to reduce $\mathrm{CMRO}_{2}$ need to be specific to the brain and it should not be assumed that measures which decrease whole body energy expenditure will necessarily have the same effect on $\mathrm{CMRO}_{2}$.
\end{abstract}

\section{$(\mathcal{F}$ Neurol Neurosurg Psychiatry 1995;59:359-367)}

Keywords: children; head injury; energy metabolism

Correspondence to:

Sir James Spence Institute of Child Health, Royal Victoria Infirmary, Queen Victoria

Road, Newcastle-upon-Tyne NE1 4LP, UK

Received 4 November 1994 and in revised form

15 March 1995

Accepted 9 June 1995

Cerebral $\mathrm{O}_{2}$ consumption $\left(\mathrm{CMRO}_{2}\right)$ accounts for about $20 \%$ of total body oxygen consumption in healthy resting adults. ${ }^{1}$ It is unclear, brain is closely related to the metabolic rate of the rest of the body either in health or illness. Furthermore, although the mediators influencing whole body metabolic rate have been described, ${ }^{2}$ it is uncertain whether these mediators affect both cerebral metabolic rate and body metabolic rate in a similar manner. Previous studies within our research group have shown that $\mathrm{CMRO}_{2}$ lies within the normal range for children and decreases significantly in the first 48 hours after severe head injury. ${ }^{3}$ Robertson et al have shown a similar decrease in whole body $\mathrm{O}_{2}$ consumption $\left(\mathrm{VO}_{2}\right)$ over time in adults with severe head injury. ${ }^{4}$ The aim of this study was to determine if the fall in $\mathrm{CMRO}_{2}$ in our group of children with severe head injury simply reflects changes in whole body metabolic rate as part of the stress response to injury, or whether the fall in $\mathrm{CMRO}_{2}$ indicates independent progressive changes in cerebral function. There are important therapeutic implications because if $\mathrm{CMRO}_{2}$ simply reflects $\mathrm{VO}_{2}$, general interventions aiming to modify the stress response and reduce metabolic rate will reduce $\mathrm{CMRO}_{2}$ concurrently. If, however, $\mathrm{CMRO}_{2}$ is determined independently from the rest of the body, then specific measures aiming to decrease it are needed. Therapeutic lowering of $\mathrm{CMRO}_{2}$ may benefit those severely head injured children with cerebral hypoperfusion resulting from raised intracranial pressure refractory to conventional treatment. however, whether the metabolic rate of the

Table 1 Clinical details of the 15 children with head injuries

\begin{tabular}{|c|c|c|c|c|c|c|}
\hline $\operatorname{Age}(y)$ & Sex & GCS & Drugs & $\begin{array}{l}\text { Duration } \\
\text { of study } \\
\text { (h) }\end{array}$ & $\begin{array}{l}\text { No of } \\
\text { measurements }\end{array}$ & $\begin{array}{l}\text { Time of first } \\
\text { measurement } \\
\text { (h) }\end{array}$ \\
\hline $3 \cdot 4$ & $F$ & $3^{\star}$ & f $1 \cdot 7-6 \cdot 7, \mathrm{~m} \mathrm{200-270}$ & 40 & 3 & 9 \\
\hline $8 \cdot 8$ & $\mathbf{M}$ & 3 & f $2 \cdot 3, \mathrm{~m} 45-180$ & 79 & 5 & 10 \\
\hline $15 \cdot 6$ & $\mathrm{~F}$ & 3 & f $0.9, \mathrm{~m} 40-75$ & 10 & 2 & 35 \\
\hline $10 \cdot 2$ & $\mathrm{~F}$ & 4 & f $2 \cdot 6-4 \cdot 3, \mathrm{~m} 35-100$ & 107 & 9 & 15 \\
\hline $14 \cdot 0$ & M & 4 & f $2 \cdot 5-3 \cdot 8$ & 178 & 11 & 10 \\
\hline $6 \cdot 4$ & $M$ & 6 & f $1 \cdot 1-6 \cdot 6, \mathrm{~m} 130-310$ & 79 & 7 & 9 \\
\hline $6 \cdot 4$ & $\mathrm{~F}$ & $6^{\star}$ & f $2 \cdot 0-4 \cdot 0, \mathrm{~m} 80$ & 55 & 6 & 11 \\
\hline 11.5 & $\mathbf{M}$ & 6 & f $4 \cdot 4-5 \cdot 8, \mathrm{~m} 85-115$ & 83 & 7 & 12 \\
\hline $12 \cdot 0$ & $M$ & 6 & f $0 \cdot 6-1 \cdot 9, \mathrm{~m} 50-75$ & 63 & 7 & 9 \\
\hline $8 \cdot 6$ & $M$ & 7 & f $3 \cdot 3-5 \cdot 0, \mathrm{~m} 33-100$ & 41 & 5 & 10 \\
\hline $9 \cdot 0$ & $\mathbf{M}$ & 7 & f $4.9, \mathrm{~m} 165-230$ & 5 & 2 & 14 \\
\hline $11 \cdot 4$ & $\mathbf{M}$ & 7 & f $1.6, \mathrm{~m} 65-95$ & 85 & 6 & 11 \\
\hline $2 \cdot 4$ & $\mathrm{~F}$ & 8 & f $6.4, \mathrm{~m} 170$ & 12 & 2 & 42 \\
\hline $2 \cdot 5$ & $\mathbf{M}$ & 8 & f $2 \cdot 1-8 \cdot 4, \mathrm{~m} 85-105$ & 23 & 3 & 25 \\
\hline $9 \cdot 9$ & $\mathbf{M}$ & 8 & f $2 \cdot 5-5 \cdot 0, \mathrm{~m} 50-100$ & 28 & 4 & 12 \\
\hline
\end{tabular}

GCS $=$ Glasgow coma score on admission; $\mathrm{f}=$ fentanyl $\left(\mu \mathrm{g} \cdot \mathrm{kg}^{-1} \cdot \mathrm{h}^{-1}\right) ; \mathrm{m}=$ midazolam $\left(\mu \mathrm{g} \cdot \mathrm{kg}^{1} \cdot \mathrm{h}^{1}\right) ;^{\star}=$ associated injuries; time of first measurement $=$ time after injury of first measurement.

\section{Patients}

The study was part of a larger project examining the hormonal and metabolic response to head injury. ${ }^{25}$ It was performed on 15 children who had sustained a severe head injury and were receiving neurointensive care. The mean age was 8.8 with a range of 2 to 15 years. Thirteen children had isolated head injuries and two children had other associated injuries. Associated injuries were defined as injuries severe enough to warrant hospital admission in their own right which is roughly equivalent to an Injury Severity Score of $\geqslant 9 .{ }^{6}$ In all cases the head injury was the most serious injury sustained. The criterion for admission to the study was a Glasgow coma score $\leqslant 8 .^{7}$ In children aged less than 4 years, the adaptation of the Glasgow coma score described by James and Trauner was used. ${ }^{8}$ The mean Glasgow coma score was 6 , range 3 to 8 . Table 1 gives further clinical details of the children. Ethical approval for the study was granted by the joint ethics committee of Newcastle Health 
Authority and University of Newcastle upon Tyne and informed written consent was obtained from the parents.

\section{Management}

The clinical care of the children was the responsibility of the neurointensive care team. All children were intubated and received elective intermittent positive pressure ventilation with mild hyperventilation, arterial $\mathrm{PCO}_{2}$ being maintained between $3.5-4.5 \mathrm{kPa}$, with a fractional inspired $\mathrm{O}_{2}$ concentration of $0 \cdot 3-0 \cdot 35$.

The children were sedated with continuous intravenous infusions of fentanyl (mean 3.4 , range $\left.\quad 0 \cdot 6-8 \cdot 4 \mu \mathrm{g} \cdot \mathrm{kg}^{-1} \cdot \mathrm{h}^{-1}\right) ; 14$ children received a simultaneous infusion of midazolam (mean 127, range $33-310 \mu \mathrm{g} \cdot \mathrm{kg}^{-1} \cdot \mathrm{h}^{-1}$ ). All children received muscle relaxants, either pancuronium or vecuronium. Seven children were given dopamine (mean 0.46 , range $0.06-0.80$ mg. $\left.\mathrm{kg}^{-1} \cdot \mathrm{h}^{-1}\right)$.

Intravenous crystalloid fluids were given at maintenance requirements or with mild fluid restriction ( $75 \%$ of requirements). Nasogastric feeds of a nutritionally complete formula were commenced 24-48 hours after the injury, increasing gradually as tolerated over two to three days.

Rectal temperature was monitored with a rectal probe (Mon-a-Therm Model 6510, Mallinckrodt) accurate to $\pm 0 \cdot 1^{\circ} \mathrm{C}$. The ambient temperature of the intensive care unit ranged from $21-26$, mean $24^{\circ} \mathrm{C}$. All children had a urinary drainage catheter and peripheral arterial catheter inserted.

\section{Methods}

Serial measurements of $\mathrm{VO}_{2}$ and $\mathrm{CMRO}_{2}$ were made in each child as soon as possible after admission to the intensive care unit and repeated every six to 24 hours until the child was no longer receiving neurointensive care. These measurements were integrated values determined over a period of 10-20 minutes. Each measurement of $\mathrm{VO}_{2}$ was followed within 5-20 minutes by measurement of $\mathrm{CMRO}_{2}$. Simultaneous measurements were not possible because of the requirement for constant volumes of inert gases in inspiratory and expired gases for indirect calorimetry. A blood sample from the indwelling arterial line was taken for determination of plasma concentrations of adrenaline, $\mathrm{T} 3$, and glucagon at the end of each measurement of $\mathrm{Vo}_{2}$. All measurements were made during periods of clinical stability, indicated by stable blood pressure, pulse rate, and temperature.

\section{MEASUREMENT OF CEREBRAL OXYGEN} CONSUMPTION $\left(\mathrm{CMRO}_{2}\right)$

Global cerebral blood flow was measured by the Kety-Schmidt technique with $10 \%$ nitrous oxide as the inert tracer. ${ }^{9}$ This method, which is based on the Fick principle, has been described in detail in a previous paper. ${ }^{10}$ The reproducibility of the measurement of cerebral blood flow has been shown to be $\pm 3 \% .^{10}$
At the end of each measurement of cerebral blood flow, arterial and superior jugular venous bulb samples $(0.5 \mathrm{ml})$ were obtained. Blood gas analysis was performed with a Radiometer analyser (Corning 1312) and the oxygen saturation and haemoglobin concentration were measured with a co-oximeter (OSM2 Hemoximeter, Radiometer). Blood oxygen content was calculated according to the equation: ${ }^{11}$

$\mathrm{O}_{2}$ content $=$

$\mathrm{Hb} \times \mathrm{O}_{2}$ sat $^{\mathrm{n}} \times 1.39+\left(0.023 \times \mathrm{PO}_{2}\right)$

where $\mathrm{Hb}=$ haemoglobin concentration in g. $100 \mathrm{ml}$ blood $^{-1} ; \mathrm{O}_{2}$ sat $^{\mathrm{n}}=\mathrm{O}_{2}$ saturation expressed as a proportion; $\mathrm{PO}_{2}=$ partial pressure of $\mathrm{O}_{2}$ in $\mathrm{kPa}$

This gives $\mathrm{O}_{2}$ content in $\mathrm{ml} .100 \mathrm{ml}$ blood $^{-1}$. It was then expressed in $\mu \mathrm{mol} . \mathrm{ml}^{-1}$ by multiplying by 0.446 .

The $\mathrm{CMRO}_{2}$ was calculated from the equation:

$$
\mathrm{CMRO}_{2}=\mathrm{CBF} \times(\mathrm{A}-\mathrm{V})
$$

where $\mathrm{CMRO}_{2}=$ cerebral $\mathrm{O}_{2}$ consumption in $\mu \mathrm{mol} \cdot \mathrm{g}^{-1} \cdot \mathrm{min}^{-1}$; $\mathrm{CBF}=$ cerebral blood flow in $\mathrm{ml} \cdot \mathrm{g}^{-1} \cdot \mathrm{min}^{-1} ; \mathrm{A}$ and $\mathrm{V}=$ arterial and cerebrovenous contents of $\mathrm{O}_{2}$ respectively in $\mu \mathrm{mol} . \mathrm{ml}^{-1}$

It should be noted that $\mathrm{CMRO}_{2}$ does not include energy production via anaerobic metabolism and thus $\mathrm{CMRO}_{2}$ may underestimate total cerebral metabolic rate. However, using measurements of arterial-cerebrovenous differences in $\mathrm{O}_{2}$ :glucose ratios and lactate concentrations, together with the knowledge that ATP production via glycolysis alone is about $1 / 18$ th of the ATP production via glycolysis and the Kreb's cycle, it can be shown that the ATP production by the brain from anaerobic metabolism accounts for only about $1 \%$ of total brain energy metabolism, with a maximum of $5 \%$, in this group of children. Thus the effect of anaerobic metabolism on total cerebral energy metabolism is small.

\section{MEASUREMENT OF WHOLE BODY OXYGEN} CONSUMPTION $\left(\mathrm{VO}_{2}\right)$

Whole body metabolic rate was measured by indirect calorimetry using a modified Douglas bag technique. ${ }^{12}$ This method has been described in detail in a previous paper and will only be outlined briefly. ${ }^{2}$ All children were ventilated with a Servo $900 \mathrm{C}$ ventilator using warmed humidified gases. A sample of the inspiratory gases and all the expiratory gases were collected into 51 and 1001 metallised gas bags (Signal Instrument Company, Camberley, Surrey) respectively, over an accurately timed period of 10-20 minutes depending on the minute volume of the child. The bags were then sealed until analysis. One litre of each of the expiratory and inspiratory gases was taken for analysis of $\mathrm{O}_{2}$ and $\mathrm{CO}_{2}$ concentrations.

Inspiratory and expiratory $\mathrm{O}_{2}$ concentrations were measured with a paramagnetic $\mathrm{O}_{2}$ analyser (Servomex 540A, Servomex, Crowborough, Sussex) modified to analyse discrete $100 \mathrm{ml}$ gas samples and to give a digi- 
tal readout. Expiratory $\mathrm{CO}_{2}$ concentrations were measured with an infrared $\mathrm{CO}_{2}$ analyser (Servomex PA404, Servomex). Each $100 \mathrm{ml}$ gas sample was dried before analysis by passing it through anhydrous calcium chloride. Gas samples were analysed in triplicate to ascertain stable results.

The volume of the remaining expired gas was measured with a dry gas meter, DTM200-4 (International Gas Apparatus Ltd, Camberley, Surrey) and expressed in terms of standard temperature and pressure and dry (STPD) conditions.

The complete indirect calorimetry system was evaluated with $\mathrm{N}_{2}$ and $\mathrm{CO}_{2}$ dilution techniques as described by Westenskow et al. ${ }^{13} \mathrm{At}$ an $\mathrm{FiO}_{2}$ of $0 \cdot 3$, the mean $\mathrm{Vo}_{2}$ recovery was 99.9 (SD 2)\%.

\section{CALCULATIONS}

The $\mathrm{VO}_{2}$ was calculated from the equation:

$$
\mathrm{Vo}_{2}=\mathrm{VE}\left[\frac{\left(1-\mathrm{FeO}_{2}-\mathrm{FeCO}_{2}\right)}{1-\mathrm{FiO}_{2}} \times \mathrm{FiO}_{2}-\mathrm{FeO}_{2}\right]
$$

(using Haldane transformation)

where $\mathrm{VO}_{2}$ is $\mathrm{O}_{2}$ consumption in $1 . \mathrm{min}^{-1}$; $\mathrm{VE}$ is expired volume in $1 . \mathrm{min}^{-1}$ at STPD; $\mathrm{FiO}_{2}$ is proportion of $\mathrm{O}_{2}$ in inspiratory gas; $\mathrm{FeO}_{2}$ is proportion of $\mathrm{O}_{2}$ in mixed expiratory gas; $\mathrm{FeCO}_{2}$ is proportion of $\mathrm{CO}_{2}$ in mixed expiratory gas. $\mathrm{VO}_{2}$ was then expressed in mmol.min ${ }^{-1}$ by multiplying by $44 \cdot 6$.

The stability of measurements of $\mathrm{VO}_{2}$ was assessed in three children, two gas collections being performed at an interval of 20 minutes in each child. The percentage relative errors for $\mathrm{VO}_{2}$ were $0.5 \%, 0.4 \%$, and $2 \%$.

\section{MEASUREMENT OF FAT FREE MASS}

To explore the relation between $\mathrm{CMRO}_{2}$ and the $\mathrm{O}_{2}$ consumption of the other metabolically active tissues of the body, $\mathrm{Vo}_{2}$ was expressed in terms of $\mathrm{kg}$ fat free mass. Fat free mass was calculated from the child's bioelectrical impedance, measured with a Holtain body composition analyser (Holtain Ltd, Crosswell, Dyfed) and the child's height and age. Fat free mass was calculated from the equations of Schaefer et al. ${ }^{14}$

\section{MEASUREMENT OF PLASMA HORMONE CONCENTRATIONS}

A $2 \mathrm{ml}$ blood sample was taken from the indwelling peripheral arterial catheter at the end of each measurement of $\mathrm{Vo}_{2}$. Blood for plasma glucagon assay was collected into a tube containing aprotinin and the remaining sample was collected into a heparinised tube. Sample tubes were stored on ice during collection and plasma for hormone assays was immediately separated and stored at $-80^{\circ} \mathrm{C}$. Plasma T3 and glucagon concentrations were determined by radioimmunoassay ${ }^{15}$ and plasma adrenaline concentrations were determined by a double isotope radioenzymatic method. ${ }^{16}$

CALCULATION OF BODY $\mathrm{O}_{2}$ CONSUMPTION INDEPENDENT OF $\mathrm{CMRO}_{2}$

The $\mathrm{VO}_{2}$ includes $\mathrm{CMRO}_{2}$, which may account for up to $34 \%$ of total $\mathrm{O}_{2}$ consumption. To compare $\mathrm{CMRO}_{2}$ with the rest of the body, a measure of body $\mathrm{O}_{2}$ consumption independent of brain was needed. To derive this, a measure of the brain's total $\mathrm{O}_{2}$ consumption was needed. Thus an estimate of brain weight was required for each child. Brain weight was estimated from the head circumference measured when any scalp or soft tissue swelling had resolved using the equation described by Winick and Rosso. ${ }^{17}$

Total brain weight $(\mathrm{kg})=$

$$
(\mathrm{HC}-20 \cdot 5)^{2}+109 \cdot 75
$$

where $\mathrm{HC}=$ head circumference in $\mathrm{cm}$.

The original equation was derived from measurements of head circumference of infants up to 1 year of age. To ascertain the predictive accuracy of the equation in older children, head circumference and brain weight were measured at postmortem in 10 adults less than 60 years of age dying from nonneurological causes, the formula applied to the data, and the results analysed. Brain weight was found to be estimated with an accuracy of $\pm 5 \%$.

Body oxygen consumption independent of brain $\left(\mathrm{BVO}_{2}\right)$ was calculated according to the equation:

$$
\begin{aligned}
\mathrm{BVO}_{2}=\frac{\mathrm{VO}_{2}-\left(\mathrm{CMRO}_{2} \times \mathrm{BW}\right)}{\mathrm{FFM}-\mathrm{BW}} \\
(\mathrm{mmol} \cdot \mathrm{kg} \text { fat free mass } \\
\end{aligned}
$$

where $\mathrm{Vo}_{2}=$ total whole body oxygen consumption (mmol.min ${ }^{-1}$ ); $\mathrm{CMRO}_{2}=$ cerebral oxygen consumption (mmol.kg brain ${ }^{-1}$. $\left.\mathrm{min}^{-1}\right) ; \mathrm{BW}=$ estimated brain weight $(\mathrm{kg})$; $\mathrm{FFM}=$ fat free mass $(\mathrm{kg})$

The $\mathrm{BVO}_{2}$ was compared with $\mathrm{CMRO}_{2}$ in mmol.kg brain ${ }^{-1} \cdot \mathrm{min}^{-1}$

\section{STATISTICAL ANALYSIS}

Plasma adrenaline concentration had a skewed distribution and underwent logarithmic transformation before analysis.

Analyses based on initial values were made with paired $t$ tests and linear regression techniques. The data set is a mixture of cross sectional and longitudinal data. To remove the between-child variation and so examine the within-child relations between different variables, the data were analysed with multilevel models ${ }^{18}$ fitted using the ML3 program. ${ }^{19}$ This methodology is related to multiple regression and produces similar regression coefficients but allows each child to contribute different numbers of observations. Results are available for within-child analyses after centring of explanatory variables. ${ }^{20}$

For graphical presentation, the within-child relations were displayed by calculating the mean for each variable for each child and expressing every observation in terms of the residual from that child's mean. By taking the residuals, the between-child variation was removed and the longitudinal component of the data could be displayed. 
Figure 1(A) Time after injury $v$ whole body $\mathrm{O}_{2}$ consumption per $\mathrm{kg}$ fat free mass $\left(\mathrm{VO}_{2}\right) ;(\mathrm{B}) \mathrm{CMRO}_{2}$ per kg brain; (C) body $\mathrm{O}_{2}$ consumption independent of brain $/ \mathrm{kg}$ fat free mass $\left(B \mathrm{O}_{2}\right)$; and $(D)$ total cerebral $\mathrm{O}_{2}$ consumption expressed as a percentage of total body $\mathrm{O}_{2}$

consumption (CMRO $\mathrm{CHO}_{2}$ (total)). Each line represents the serial measurements obtained from each child.
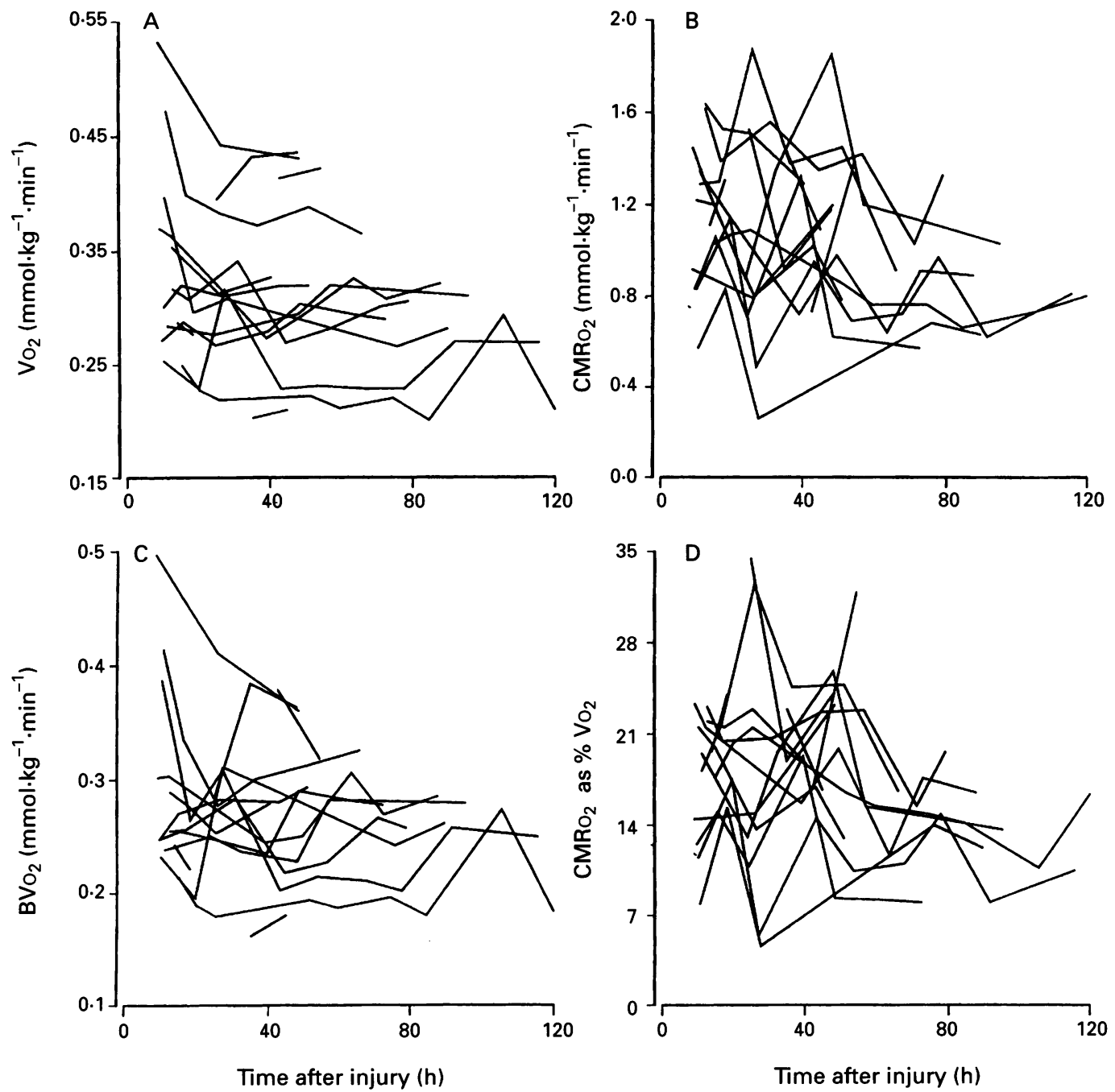

Results

A total of 79 serial measurements of $\mathrm{VO}_{2}$, $\mathrm{CMRO}_{2}$ consumption, and plasma hormone concentrations were performed on the 15 children. The median number of measurements performed in each child was five, range two to 11. The median duration of each study was 55 hours, range 5-178 hours. The median time between injury and the first measurement in all 15 children was 11 hours, range 9-42 hours. Table 1 gives further details of the results.

WHOLE BODY OXYGEN CONSUMPTION AFTER SEVERE HEAD INJURY

Figure 1A shows $\mathrm{VO}_{2}$ per kg of fat free mass over the first 120 hours after the head injury. There was a statistically significant fall in $\mathrm{Vo}_{2}$ over time from a mean of 0.34 $\mathrm{mmol} \cdot \mathrm{kg}^{-1} \cdot \mathrm{min}^{-1}$ at a mean of 12 hours to $0.30 \mathrm{mmol} . \mathrm{kg}^{-1} \cdot \mathrm{min}^{-1}$ at 24 hours after the injury (paired $t$ test $\mathrm{P}=0.005,95 \% \mathrm{CI}$ -0.063 to -0.015 ).

There was no evidence of a relation between $\mathrm{VO}_{2}$ and Glasgow coma score on admission $(P=0.32, r=-0.31)$.

There was no evidence for an effect of enteral feeding on $\mathrm{VO}_{2}$. The mean $\mathrm{VO}_{2}$ in the 46 observations made in the unfed state was $0.30 \mathrm{mmol} . \mathrm{kg}^{-1} \cdot \mathrm{min}^{-1}$, whereas the mean $\mathrm{Vo}_{2}$ in the 33 observations made in the fed state was $0.31 \mathrm{mmol} \cdot \mathrm{kg}^{-1} \cdot \mathrm{min}^{-1}$ (unpaired $t$ test $\mathrm{P}$ $=0.40,95 \% \mathrm{CI}$ for difference -0.04 to 0.02 ).

\section{CEREBRAL OXYGEN CONSUMPTION AFTER}

Figure 1B shows $\mathrm{CMRO}_{2}$ over the first 120 dency for $\mathrm{CMRO}_{2}$ to decrease over time from a mean of $1.15 \mathrm{mmol} . \mathrm{kg}^{-1} \cdot \mathrm{min}^{-1}$ at a mean of 12 hours to $1.04 \mathrm{mmol} \cdot \mathrm{kg}^{-1} \cdot \mathrm{min}^{-1}$ at 48 hours but this decrease did not achieve statistical significance (paired $t$ test $\mathrm{P}=0.31,95 \% \mathrm{CI}$ -0.28 to 0.097$)$. The $\mathrm{CMRO}_{2}$ was within the reference range for normal resting children for 78 measurements and depressed for one measurement. $^{21}$

Over the first 120 hours after the head injury, mean cerebral blood flow was 0.47 $1 . \mathrm{kg}^{-1} \cdot \mathrm{min}^{-1}$, with a range of $0 \cdot 18-1 \cdot 8$ $1 . \mathrm{kg}^{-1} \cdot \mathrm{min}^{-1}$. There was a statistically significant increase in cerebral blood flow over time from a mean of $0.361 . \mathrm{kg}^{-1} \cdot \mathrm{min}^{-1}$ at 12 hours to $0.541 . \mathrm{kg}^{-1} \cdot \mathrm{min}^{-1}$ at 48 hours after the injury (paired $t$ test $\mathrm{P}=0.006,95 \%$ CI 0.05 to $0 \cdot 25)$. Cerebral blood flow was within the reference range for normal children for 62 measurements, depressed for 16, and raised in one measurement. ${ }^{21}$ Thus the changes that occurred in $\mathrm{CMRO}_{2}$ over time were not associated with parallel changes in cerebral blood
SEVERE HEAD INJURY hours after the head injury. There was a ten- 
flow and there was evidence of absolute hyperaemia in only one measurement.

Initial values of $\mathrm{CMRO}_{2}$ showed a significant positive correlation with Glasgow coma score $(\mathrm{P}=0.006, r=0.71)$ indicating that the most severely injured children had the lowest cerebral metabolic rates.

There was no evidence of a relation between cerebral blood flow on admission and Glasgow coma score $(P=0 \cdot 44, r=0 \cdot 216)$.

BODY OXYGEN CONSUMPTION INDEPENDENT OF BRAIN AFTER SEVERE HEAD INJURY

Figure $1 \mathrm{C}$ shows $\mathrm{BVO}_{2}$ per kg fat free mass over the first 120 hours after the head injury. There was a significant fall in $\mathrm{BVO}_{2}$ from mean $0.30 \mathrm{mmol} \cdot \mathrm{kg}^{-1} \cdot \mathrm{min}^{-1}$ at a mean of 12 hours to mean $0.26 \mathrm{mmol} \cdot \mathrm{kg}^{-1} \cdot \mathrm{min}^{-1}$ at 24 hours (paired $t$ test $\mathrm{P}=0.02,95 \% \mathrm{CI}-0.066$ to $-0.005)$.

There was no evidence of a relation between $\mathrm{BVO}_{2}$ on admission and Glasgow coma score $(P=0 \cdot 13, r=-0.46)$.

CEREBRAL OXYGEN CONSUMPTION AS A PERCENTAGE OF TOTAL BODY OXYGEN CONSUMPTION AFTER SEVERE HEAD INJURY Figure 1D shows cerebral $\mathrm{O}_{2}$ consumption as a percentage of $\mathrm{VO}_{2}\left(\mathrm{CMRO}_{2} / \mathrm{VO}_{2}\right)$ over the first
120 hours after the head injury. The total $\mathrm{CMRO}_{2}$ accounted for a mean of $17 \% \mathrm{VO}_{2}$ with a wide range of $5-34 \%$.

There was no evidence of a significant change of the percentage of $\mathrm{VO}_{2}$ accounted for by $\mathrm{CMRO}_{2}$ from 12 hours, mean $17.6 \%$, until 24 hours, mean $18.6 \%$ (paired $t$ test $\mathrm{P}=$ $0.95,95 \% \mathrm{CI}-3.93$ to 4.18 ) and 48 hours, mean $18.2 \%$, after the injury (paired $t$ test $\mathrm{P}=0 \cdot 76,95 \% \mathrm{CI}-3 \cdot 10$ to $4 \cdot 12$ ).

There was a statistically significant relation between the percentage of $\mathrm{VO}_{2}$ accounted for by $\mathrm{CMRO}_{2}$ on admission and Glasgow coma score $(P=0.007, r=0.73)$. As the percentage of $\mathrm{VO}_{2}$ accounted for by $\mathrm{CMRO}_{2}$ may change with age, the effect of age on the relation was analysed by multiple regression. The significant positive relation between $\mathrm{CMRO}_{2} \mathrm{NO}_{2}$ and Glasgow coma score remained $(P=0.005)$.

RELATION BETWEEN CEREBRAL OXYGEN CONSUMPTION AND BODY OXYGEN CONSUMPTION

There was no evidence of a significant relation between $\mathrm{CMRO}_{2}$ and $\mathrm{BVO}_{2}$. Analysis of the raw data showed an apparent negative relation between $\mathrm{CMRO}_{2}$ and $\mathrm{BVO}_{2}$ (regression coefficient $=-0 \cdot 16,95 \% \quad \mathrm{CI}-0.24$ to -0.08$)$
Figure 2 Within-child relation between $\mathrm{BVO}_{2}$ and possible mediators. Each graph shows the residuals from the mean for $\mathrm{BVO}_{2}$ and each possible mediator. $(A) \log$ adrenaline, $(B)$ T3, and (C) glucagon.
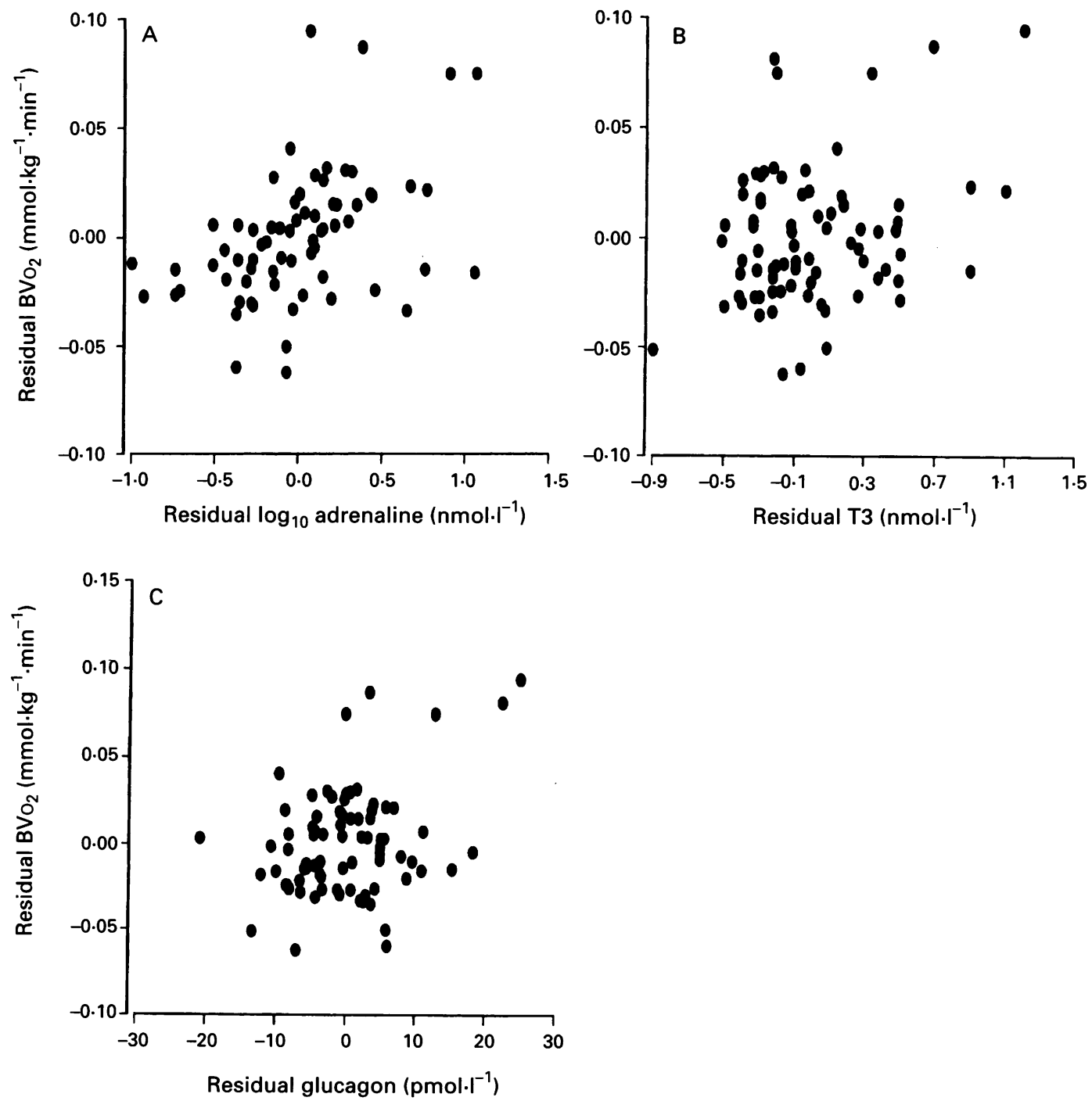
Table 2 Details of analysis by multilevel modelling (within-child relation between $\mathrm{BVO}_{2}$ and $\mathrm{CMRO}_{2}$ and possible mediators)

\begin{tabular}{|c|c|c|c|c|c|c|}
\hline \multirow[b]{2}{*}{ Variable } & \multicolumn{3}{|l|}{$\mathrm{BVO}_{2}$} & \multicolumn{3}{|l|}{$\mathrm{CMRO}_{2}$} \\
\hline & $\begin{array}{l}\text { Regression } \\
\text { coefficient }\end{array}$ & $\begin{array}{l}\text { Standard } \\
\text { error }\end{array}$ & $P$ value & $\begin{array}{l}\text { Regression } \\
\text { coefficient }\end{array}$ & $\begin{array}{l}\text { Standard } \\
\text { error }\end{array}$ & $P$ value \\
\hline $\begin{array}{l}\log _{10} \text { adrenaline } \\
\text { T3 } \\
\text { Glucagon }\end{array}$ & $\begin{array}{l}0.032 \\
0.023 \\
0.0013\end{array}$ & $\begin{array}{l}0.0085 \\
0.0096 \\
0.0005\end{array}$ & $\begin{array}{l}0.0002 \\
0 \cdot 017 \\
0 \cdot 005\end{array}$ & $\begin{array}{c}-0.0092 \\
0.15 \\
0.0047\end{array}$ & $\begin{array}{l}0.071 \\
0.068 \\
0.0035\end{array}$ & $\begin{array}{l}0 \cdot 89 \\
0 \cdot 023 \\
0 \cdot 18\end{array}$ \\
\hline
\end{tabular}

Figure 3 Within-child relation between $\mathrm{CMRO}_{2}$ and possible mediators. Each graph shows the residuals from the mean for $\mathrm{CMRO}_{2}$ and each possible mediator. (A) $\log _{1}$ adrenaline, $(B) T 3$, and (C) glucagon.

but there are statistical problems interpreting this regression as $\mathrm{BVO}_{2}$ must be calculated by subtracting the total $\mathrm{CMRO}_{2}$ from $\mathrm{VO}_{2}$. The observed metabolic rates differ from the true values by errors of measurement, and the presthe regression will induce a negative bias in the estimate of the regression coefficient. A heuristic approach to correcting this bias is outlined in the appendix. The adjusted regression coefficient is 0.01 with interval estimates of -0.10 to 0.11 , indicating no evidence of a relation between $\mathrm{CMRO}_{2}$ and $\mathrm{BVO}_{2}$.

The $\mathrm{CMRO}_{2}$ and $\mathrm{BVO}_{2}$ are used to indicate cerebral metabolic rate and body metabolic ence of the error in the $\mathrm{CMRO}_{2}$ on both sides of rate independent of brain. This is generally acceptable as the most important measurement of energy expenditure is $\mathrm{O}_{2}$ consumption. After injury, however, respiratory quotient $(\mathrm{RQ})$ values, which reflect the type of
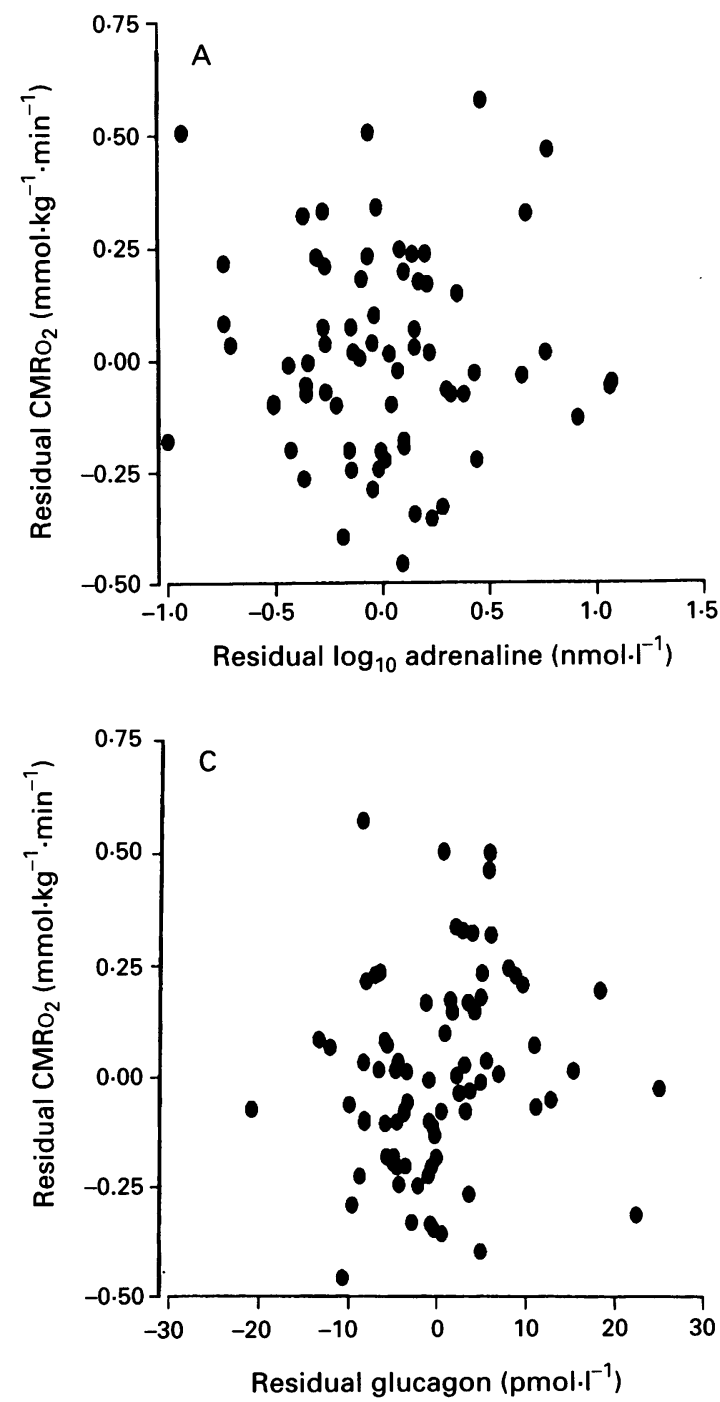

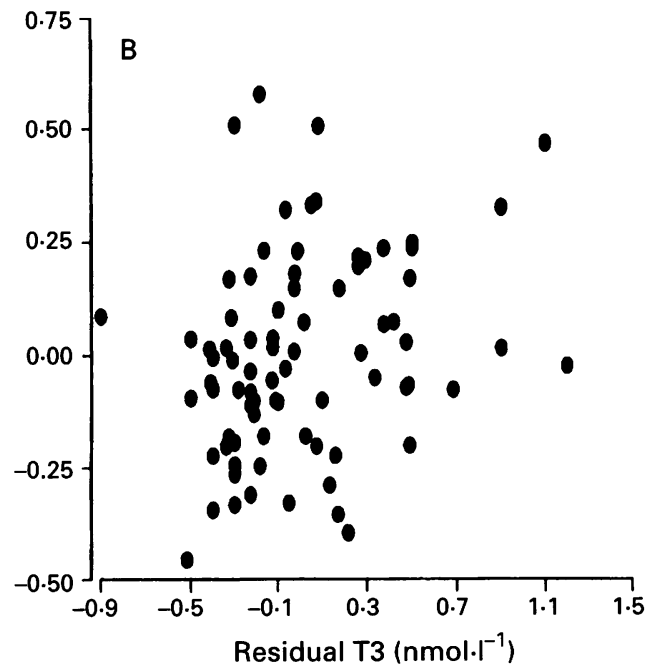

fuel oxidised, may be quite variable and thus have a moderate effect on the relation between metabolic rate and $\mathrm{O}_{2}$ consumption. The RQ of the brain may be taken as 1 . Glucose, the predominant fuel of the brain has an RQ of 1 , and the ketone bodies $\beta$-hydroxybutyrate and acetoacetate give a combined RQ of about 1 if they are utilised in roughly equal quantities. The RQ of the whole body varied from 0.7 to 1.0 in this study with an interquartile range of 0.77 to 0.82 . If the RQ of the brain is taken as 1 , the RQ of the rest of the body can be calculated from the formula:

$\mathrm{RQ}_{\text {total }}=\lambda \mathrm{RQ}_{\text {brain }}+(1-\lambda) \mathrm{RQ}_{\text {body }}$

where $\lambda=\mathrm{CMRO}_{2}$ (total) $/ \mathrm{Vo}_{2}$

The total energy expenditure of the brain and the rest of the body could then be calculated from the Weir formula. ${ }^{22}$ From these results, which allow for the effects of oxidation of different fuels within the body, it could be shown that there was no evidence for a positive relation between cerebral metabolic rate and the metabolic rate of the rest of the body.

WITHIN CHILD RELATION BETWEEN BODY $\mathrm{O}_{2}$ CONSUMPTION INDEPENDENT OF BRAIN AND POSSIBLE MEDIATORS

Using multilevel modelling, log adrenaline, T3, and glucagon were all found to have inde- 
pendent significant relations with whole body energy expenditure in a previous study. ${ }^{2}$ Thus the relation of these variables with $\mathrm{BVO}_{2}$ and $\mathrm{CMRO}_{2}$ were analysed.

Figure 2 shows the within-child relations between $\mathrm{BVO}_{2}$ and possible mediators. With multilevel modelling, significant positive relations were found between $\mathrm{BVO}_{2}$ and log adrenaline $(P=0.0002), T 3 \quad(P=0.017)$, and glucagon $(P=0.005)$. Table 2 shows further details of the results of the statistical analysis.

WITHIN CHILD RELATION BETWEEN CEREBRAL $\mathrm{O}_{2}$ CONSUMPTION AND POSSIBLE MEDIATORS Figure 3 shows the within-child relations between $\mathrm{CMRO}_{2}$ and possible mediators. Using multilevel modelling, a significant positive relation was found between $\mathrm{CMRO}_{2}$ and T3 $(P=0.023)$. There was no evidence of a relation between $\mathrm{CMRO}_{2}$ and log adrenaline $(P=0.887)$ or glucagon $(P=0 \cdot 18)$. Table 2 gives further details of the results of the statistical analysis.

\section{Discussion}

In our study there was no evidence of a positive relationship between $\mathrm{CMRO}_{2}$ and $\mathrm{BVO}_{2}$ after severe head injury in children. To the best of our knowledge, this relation has not been examined before in either healthy or injured children.

The absence of a positive relation between $\mathrm{CMRO}_{2}$ and $\mathrm{BVO}_{2}$ was supported by the finding that the percentage of $\mathrm{VO}_{2}$ accounted for by $\mathrm{CMRO}_{2}$ varied considerably both between and within children, regardless of the age of the child with the most severely injured children having the lowest percentage of $\mathrm{VO}_{2}$ accounted for by the brain.

From experimental work, there is accumulating evidence that the prefrontal cortex and sympathetic nervous system may be important in influencing energy balance in the whole resting animal. ${ }^{23}$ The central nervous effect on resting metabolic rate is largely mediated by circulating thyroid hormones and adrenaline, which affect all somatic tissues. ${ }^{24}$ The environment of the brain, however, is likely to be different from the rest of the body, largely because of the presence of the blood-brain barrier. Thus it is possible that the metabolic rate of the brain and the rest of the body may be determined independently in health. After severe head injury, local factors induced by trauma and stress may also have important influences on $\mathrm{CMRO}_{2}$ without affecting $\mathrm{BVO}_{2}$, thus reducing the likelihood of finding a close positive relation between $\mathrm{CMRO}_{2}$ and $\mathrm{BVO}_{2}$.

In our study, the hormonal mediators shown to have a stimulatory effect on $\mathrm{BVO}_{2}$ were adrenaline, $\mathrm{T} 3$, and glucagon. The positive effects of the hormones on $\mathrm{BVO}_{2}$ may be predicted from knowledge of their action at a cellular level, and from results of studies of the systemic administration of these hormones. ${ }^{25-27}$

$\mathrm{By}$ contrast with $\mathrm{BVO}_{2}$, the only mediator shown to have a positive effect on $\mathrm{CMRO}_{2}$ was
T3. This suggests that $\mathrm{CMRO}_{2}$ is not determined by the whole body stress response after head injury.

A question of fundamental importance is the integrity of the blood-brain barrier after head injury. In normal circumstances the blood-brain barrier is impermeable to catecholamines and glucagon but there is a specific carrier enabling T3 to cross into brain tissue. $^{2829}$ If the blood-brain barrier remained intact after head injury, the relations between $\mathrm{CMRO}_{2}$ and plasma hormone concentrations could be readily explained. Many stressful events in experimental animals, including hypoxia, immobilisation, and sepsis, however, have been shown to result in a raised $\mathrm{CMRO}_{2}$, where it is proposed that the integrity of the blood-brain barrier is disrupted allowing catecholamines to cross into the brain and stimulate $\mathrm{CMRO}_{2} \cdot{ }^{30-34}$ The blood-brain barrier has been shown to be disrupted in experimental head injury. There is evidence, however, that the disruption tends to be focal and, although the duration of the perturbation may vary, it is probably short lived. ${ }^{35} 36$ These conclusions would be supported by the findings in the present study of a lack of relation between $\mathrm{CMRO}_{2}$ and high systemic concentrations of catecholamines.

Impaired utilisation of $\mathrm{O}_{2}$ has been found globally in septic shock ${ }^{37}$ and in the brain after head injury (unpublished data). The $\mathrm{CMRO}_{2}$ was positively related with Glasgow coma score on admission and the most severely injured children had the lowest percentage of whole body energy expenditure accounted for by the brain, regardless of the age of the child. An alternative explanation for the lack of relation between systemic catecholamines and $\mathrm{CMRO}_{2}$ may, therefore, be an impaired ability for neural and glial cells to utilise $\mathrm{O}_{2}$ after trauma.

The weak but significant positive relation between $\mathrm{CMRO}_{2}$ and plasma $\mathrm{T} 3$ concentration is interesting. Although $\mathrm{T} 3$ has been found to stimulate $\mathrm{O}_{2}$ consumption in many tissues, ${ }^{38}$ it has previously been shown in animal models to have a minimal effect on brain tissue. ${ }^{3940}$ This has always been perplexing because of the large numbers of $\mathrm{T} 3$ receptors within the brain and has been explained by the proposal that T3 has other metabolic effects within the brain. ${ }^{41}$ These influences include effects on adrenergic receptors ${ }^{42}$ and stimulation of synthesis of nerve growth factor, ${ }^{43}$ both of which are potentially important in traumatic encephalopathy. It is interesting to speculate that T3 may stimulate $\mathrm{O}_{2}$ consumption in some cell types within the brain in unusual circumstances, such as trauma, giving rise to the positive relation found.

In conclusion, after severe head injury there was no evidence for a positive relation between the metabolic rate of the brain and the rest of the body. Although $\mathrm{BVO}_{2}$ was influenced by the whole body stress response to injury, there was no evidence of a similar effect on $\mathrm{CMRO}_{2}$. It is not clear whether $\mathrm{CMRO}_{2}$ and $\mathrm{BVO}_{2}$ are positively related in health and this relation is then abolished after head injury or whether 
$\mathrm{CMRO}_{2}$ and $\mathrm{BVO}_{2}$ are always determined independently. Studies to examine the relation between $\mathrm{CMRO}_{2}$ and $\mathrm{BVO}_{2}$ in health would be needed to resolve this issue.

The important clinical message of this study is that $\mathrm{CMRO}_{2}$ needs to be measured directly after severe head injury and not inferred from measurements of whole body energy expenditure. Medical interventions aiming to reduce $\mathrm{CMRO}_{2}$ after severe head injury in children need to be specific to the brain and it should not be assumed that measures which decrease whole body energy expenditure will necessarily have the same effect on $\mathrm{CMRO}_{2}$.

We thank the medical and nursing staff of the intensive care unit and the consultant neurosurgeons who allowed us to study their patients. We thank Dr P Sharples for her help with cerebra blood flow measurements. We acknowledge the assistance of blood flow measurements. We acknowledge the assistance of Ms A Burnett and Mr S Turner of Newcastle University, Professor S Bloom and Dr $M$ Ghatei of Hammersmith Hospital, London, and $\mathrm{Mr} \mathrm{M}$ Ashby and Professor M Brown of Department of Clinical Pharmacology, Cambridge, for thei help with the assays performed in this study. DSFM was supported by the Scientific and Research Committee of Newcastle Health Authority and by the Medical Research Council. We gratefully acknowledge additional financial support from the Intensive Care Society, the Buttle Trust, the Mason Medical

\section{Appendix}

As outlined there is a statistical problem in interpretation of the regression coefficient of the metabolic rate of the rest of the body when it is related to total $\mathrm{CMRO}_{2}$ $(-0.160,95 \%$ CI -0.243 to -0.076$)$ because the metabolic rate of the rest of the body must be calculated by subtracting $\mathrm{CMRO}_{2}$ from the metabolic rate of the whole body, thereby inducing a negative bias. Determining the amount of this bias is not straightforward and depends on quantities, the values of which are not known with any certainty: a heuristic approach to this problem is outlined below.

Suppose the true total cerebral, whole body, and rest of body metabolic rates of an individual are denoted by $\mathrm{X}, \mathrm{Y}$, and $\mathrm{Z}=\mathrm{Y}-\mathrm{X}$. The observed total cerebral and whole body metabolic rates are $x=\mathrm{X}+\varepsilon_{1}$ and $\mathrm{y}=$ $\mathrm{Y}+\varepsilon_{2}$ where $\varepsilon_{1}$ and $\varepsilon_{2}$ are measurement errors with variances $\delta_{1}^{2}$ and $\delta_{2}^{2}$ respectively. If we assume the regression of $\mathrm{X}$ on $\mathrm{Z}$ has coefficient $\beta$, then if the metabolic rates of the brain and the rest of the body are unrelated, $\beta=0$. The observed regression coefficient of $x$ on $\mathrm{z}=\mathrm{y}-x$ will not be $\beta$ but

$$
\beta\left[\frac{\sigma^{2}-\delta_{1}^{2}-\delta_{2}^{2}}{\sigma^{2}}\right]-\frac{\delta_{1}^{2}}{\sigma^{2}}
$$

where $\sigma^{2}$ is the variance of $z$. Separate analyses suggested reasonable values for $\sigma^{2}$ and $\delta_{2}^{2}$ of 0.6 and 0.025 . The variance of the error in total $\mathrm{CMRO}_{2}$ is less well known but a reasonable value is between 0.05 and $0 \cdot 15$. Taking $\delta_{1}^{2}=0 \cdot 1$ and inverting the above expression gives an adjusted estimate of 0.010 with corresponding interval estimate $(-0.091$ to 0.110$)$. Varying $\delta_{1}^{2}$ from 0.05 to 0.15 gives similarly equivocal interval estimates.

1 Grande F. Energy expenditure of organs and tissues. In: Kinney JM, eds. Assessment of energy metabolism in health and disease. Columbus: Ross Laboratories, 1980:88-92.
Matthews DSF, Aynsley-Green A, Matthews JNS, Bullock Matthews DSF, Aynsley-Green A, Matthews JNS, Bullock
RE, Cooper BG, Eyre JA. The effect of severe head $\mathrm{RE}$, Cooper BG, Eyre JA. The effect of severe head injury on whole body energy expenditure and its possible hormonal

3 Sharples PM, Stuart AG, Matthews DSF, Aynsley-Green A, Eyre JA. Cerebral blood flow and metabolism in children with severe head injury. Part 1: relation to age, Glasgow coma score, outcome, intracranial pressure, and time after injury. $\mathcal{F}$ Neurol Neurosurg Psychiatry 1995;58:145-52.

4 Robertson CS, Clifton GL, Grossman RG, Ou C-N, Goodman JC, Borum P, et al. Alterations in cerebral injury. F Trauma 1988;28:1523-32.

5 Matthews DSF, Bullock RE, Matthews JNS, AynsleyGreen A, Eyre JA. The temperature response to severe head injury and the effect on body energy expenditure and cerebral oxygen consumption. Arch Dis Child 1995;72:507-15.

6 Baker SP, O'Neill B, Haddon W, Long W. The injury severity score: a method for describing patients with multiple injuries and evaluating emergency care. $\mathcal{F}$ Trauma 1974;14:187-96.

7 Teasdale G, Jennett B. Assessment of coma and impaired consciousness. Lancet 1974;ii:81-4.

8 James HE, Trauner DA. The Glasgow coma scale. In: James HE, Anas NG, Perkin RM, eds. Brain insults in infants and

9 Kety SS, Schmidt CF. The nitrous oxide method for the quantitative determination of cerebral blood flow in man: quantitative determination of cerebral blood flow in man: 27:476-83.

10 Sharples PM, Stuart AG, Aynsley-Green A, Heaviside D, Pay DA, McGann A, et al. A practical method of serial bedside measurement of cerebral blood flow and metabolism during neurointensive care. Arch Dis Child 1991; 66:1326-32

11 Benumof JL. Respiratory physiology and respiratory function during anaesthesia. In: Miller RD, eds. Anaesthesia. New York: Churchill Livingstone, 1986:1115-63.

12 Douglas CG. A method for determining the total respiratory exchange in man. Proceedings of the Physiological Society $1911 ; 17-8$

13 Westenskow DR, Cutler CA, Wallace WD. Instrumentation for monitoring gas exchange and meta-
bolic rate in critically ill patients. Crit Care Med 1984;12: bolic rate $183-7$.

14 Schaefer F, Georgi M, Zieger A, Scharer K. Usefulness of bioelectrical impedance and skinfold measurements in predicting fat-free mass derived from total body potassium in children. Pediatr Res 1994;35:617-24.

15 Christofides ND. Pancreatic Glucagon. In: Bloom SR Long R, eds. Radioimmunoassay of gut regulatory peptides. London: WB Saunders, 1982:74-9.

16 Brown MJ, Jenner DA. Novel double-isotope technique for enzymatic assay of catecholamines, permitting high precision, sensitivity and plasma sample capacity. Clin $S c i$ $1981 ; 61: 591-8$.

17 Winick M, Rosso P. Head circumference and cellular growth of the brain in normal and marasmic children. growth of the brain in

18 Goldstein H. Multilevel models in educational and social research. Oxford: Charles Griffin, 1987.

19 Prosser R, Rasbash J, Goldstein H. ML3: Software for threelevel analysis. London: Institute of Education, 1991.

20 Raudenbush S. "Centering" predictors in multilevel analysis: choices and consequences. Multilevel Modelling Newsletter 1989;1:10-2.

21 Settergren G, Lindblad BS, Persson B. Cerebral blood flow and exchange of oxygen, glucose, ketone bodies, lactate, Paediatrica Scandinavica 1980;69:457-65.

22 Weir JB. New methods for calculating metabolic rate with special reference to protein metabolism. I Physiol 1949;109:1-9.

23 McGregor IS, Menendez JA, Atrens DM, Lin HQ Prefrontal cortex $a_{2}$ adrenoceptors and energy balance. Brain Res Bull 1991;26:683-91.

24 James WPT. Endocrine control of energy balance. New Aspects of Clinical Nutrition 1983;31-42.

25 Hafner RP, Brown GC, Brand MD. Thyroid-hormone control of state-3 respiration in isolated rat liver mitochondria. Biochem $\mathcal{F}$ 1990:265:731-4.

26 Staten MA, Matthews DE, Cryer PE, Bier DM. Physiological increments in epinephrine stimulate metabolic rate in humans. Am $\mathcal{F}$ Physiol 1987;253:E322-30.

27 Bessey PQ, Watters JM, Aoki TT, Wilmore DW. Combined hormonal infusion simulates the metabolic Combined hormonal infusion simulates the

28 Watanabe A, Fujiwara M, Nagashima H. Glucagon-like polypeptide and insulin contents in the brain from acute polypeptide and insulin contents in the brain from acute

29 Pardridge WM. Carrier-mediated transport of thyroid hormones through the rat blood-brain barrier: primary role of albumin-bound hormone. Endocrinology 1979;105: 605-12.

30 Berntman L, Carlsson C, Siesjo BK. Cerebral oxygen consumption and blood flow in hypoxia: influence of sympathoadrenal activation. Stroke 1979;10:20-5.

31 Carlsson C, Hagerdal M, Kaasik AE, Siesjo BK. A catecholamine-mediated increase in cerebral oxygen uptake during immobilisation stress in rats. Brain Res 1977 119:223-31.

32 Ekstrom-Jodal B, Haggendal J, Larsson LE, Westerlind A Cerebral hemodynamics, oxygen uptake and cerebral Cerebral hemodynamics, oxygen uptake and cerebral arteriovenous differences of catecholamines following E coli endoto

33 Bryan RM. Cerebral blood flow and energy metabolism during stress. Am $\mathcal{F}$ Physiol 1990;259:H269-80.

34 MacKenzie ET, McCulloch J, Harper AM. Influence of MacKenzie ET, McCulloch J, Harper AM. Influence of
endogenous norepinephrine on cerebral blood flow and metabolism. Am $\mathcal{f}$ Physiol 1976;231:489-94.

35 Shapira Y, Setton D, Artru AA, Shohami E. Blood-brain barrier permeability, cerebral edema, and neurologic function after closed head injury in rats. Anesth Analg 1993;77:141-8.

36 Persson L, Hansson HA, Sourander P. Extravasation, spread and cellular uptake of Evans blue-labelled albu- 
min around a reproducible small stab-wound in the rat brain. Acta Neuropathol 1976;34:125-36.

37 Siegel JH, Cerra FB, Coleman B, Giovannini I, Shetye $M$ Border JR, McMenamy RH. Physiological and metabolic correlations in human sepsis. Surgery 1979;86: 163-93.

38 Guernsey DH, Edelman IS. Regulation of thermogenesis by thyroid hormones. In: eds. Molecular basis of thyroid hormone action. New York: Academic Press, 1983: 293-324.

39 Schwartz HL, Oppenheimer JH. Ontogenesis of 3,5,3'triiodothyronine receptors in neonatal rat brain: dissociation between receptor concentration and stimulation of oxygen consumption by 3,5,3'-triiodothyronine. of oxygen consumption by
Endocrinology 1978;103:943-8.
40 Barker SB, Klitgaard HM. Metabolism of tissues excised from thyroxine-injected rats. Am $f$ Physiol 1952;170: from $81-6$.

41 Schwartz HL, Oppenheimer JH. Nuclear triiodothyronine receptor sites in brain: probable identity with hepatic receptors and regional distribution. Endocrinology 1978; 103:267-73.

42 Gross G, Brodde OE, Schumann HJ. Effects of thyroid hormone deficiency on pre- and post-synaptic noradrenergic mechanisms in the rat cerebral cortex. Arch Int Pharmacodyn Ther 1980;244:219-30.

43 Walker P, Weichsel Jr ME, Fisher DA, Guo SM, Fisher DA. Thyroxine increases nerve growth factor concentration in adult mouse brain. Science 1979;204: 427-9.

\section{NEUROLOGICAL STAMP}

\section{Convallari majalis (lily of the valley) (also known as Our Lady's tears, ladder to heaven)}

Herbalists as far back as the 16th century recommended the blossoms of the lily of the valley soaked in wine for strengthening the memory and soothing inflamed eyes. Soaked in water it was said to ease gout. These remedies (called golden water) were so highly valued that they were stored in gold or silver vessels. Another of the age old uses of the plant was for treatment of heart ailments. Like foxglove, the plant strengthens the heart beats although its effects are milder.

Subject to many legends its white flowers became a symbol of the Virgin Mary, was called Our Lady's tears, and appeared in many paintings of the Virgin. The even, step-like, arrangements of the flowers along the stalk inspired medieval monks to name the plant ladder to heaven; and its fragrance was said to attract nightingales.

Lily of the valley is shown here on a stamp issued by Bulgaria in 1968 (Stanley Gibbons 1853, Scott 1730) illustrating medicinal plants and herbs.

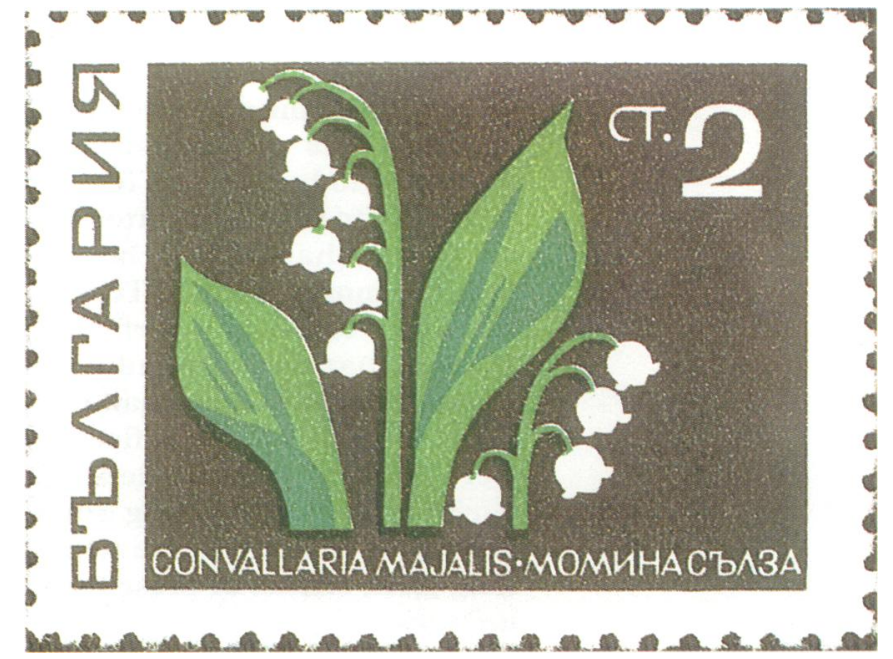

